ESJ Humanities

\title{
Putting Citizens in Front of the Dilemma Voting VS Health Protection: The Biggest Challenge to Avoid by the Albanian Authority in the 2021 Parliamentary Election
}

\author{
Irena Toshkallari, PhD Candidate \\ University of Tirana, Albania
}

Doi:10.19044/esj.2021.v17n20p16

Submitted: 02 March 2021

Accepted: 24 June 2021

Published: 30 June 2021
Copyright 2021 Author(s)

Under Creative Commons BY-NC-ND

4.0 OPEN ACCESS

Cite As:

Toshkallari I. (2021). Putting Citizens in Front of the Dilemma Voting VS Health Protection: The Biggest Challenge to Avoid by the Albanian Authority in the 2021 Parliamentary Election. European Scientific Journal, ESJ, 17(20), 16. https://doi.org/10.19044/esj.2021.v17n20p16

\section{Abstract}

In a relatively new and fragile democracy like Albania, with only 30 years of life in this post-communist period, the COVID-19 Pandemic placed the authorities in the face of even more difficult challenges in holding free and fair elections that are uncontested and legitimate. Finding a balance between elections that meet the criteria of being democratic and protecting the lives of citizens is one of the chief objectives for Albanian authorities. This is likened to be the case of many other countries that had elections during the COVID19 period. Although COVID-19 virus is not selective as to whom it will infect, some specific groups such as the elderly people with underlying health conditions tend to manifest more severe symptoms. Countries are responsible for adapting the voting system to ensure public safety during the pandemic by implementing a diverse range of alternative voting mechanisms. Policymakers in the design process of measures have to take into consideration these vulnerable groups and also the individuals who show symptoms on the voting day due to SARS, CoV-2, or they may be hospitalized or be quarantined on the voting day. This paper focuses on analyzing the measures that Albanian authorities have envisaged to ensure the right to vote for these specific groups. After evaluating the decisions and instructions of the responsible authorities for the organization and administration of elections in Albania, it can be concluded that based on the subject of this research paper, no specific measures was undertaken for any of the groups mentioned above to ensure a 
safe voting process. The lack of this can probably lead to exclusive and not inclusive elections.

Keywords: Election in Albania, inclusive election, COVID-19, Right to vote, precautions, principle, measures

\section{Introduction}

"COVID-19 is a public health emergency that is fast becoming a human rights crisis" (Antonio Guterres, General Secretary of UN, 2020). It threatens not only the health of citizens but also the economy, social, and political life. There are four fundamental instruments of democratic citizen engagement which are precise: elections along with free and effective political organization, peaceful social mobilization, and open/high quality public deliberation. More so, all of them have been affected in the context of a pandemic where in-person interactions pose a public health risk (Calva, 2021). However, the focus of this research paper is one of these instruments, i.e., election.

The Universal Declaration of Human Rights in Article 21 states: a. everyone has the right to take part in the government of his/her country directly or through freely chosen representatives; $b$. The will of the people shall be the basis of the authority of government, and this will be expressed in periodic and genuine elections which shall be by universal and equal suffrage and shall be held by secret ballot or by equivalent free voting procedures (Ferguson et al., 2003).

No voters should have to choose between their safety and their fundamental right to vote; and with the right policies, planning, and practice in place, they will not have to (Brennan Center for Justice \& Infection Diseases Society of America, 2020). However, the process of choosing "the right policy" is the biggest challenge of states, elections, and health authorities because they had to choose between a series of elements and mechanisms to ensure inclusive participation.

While it is true that "COVID-19 does not discriminate" in terms of who is infected, certain groups are at greater risk of poor outcomes and are therefore taking extra precautions that may affect their ability to participate (The Commonwealth, 2020, pg.6). According to international health organization, COVID-19 vulnerable groups are included such as the elderly (people over 60 years old) and people with chronic disease, e.g., hypertension, diabetes, cardiovascular disease, chronic respiratory disease, and immune suppression (European Centre for Disease Prevention and Control, 2020). The obligation of the authorities is to manage the elections to take precautions to hold safe elections. This aims to boost the confidence of voters that participating in the elections does not affect their health. Are the responsible 
structures in Albania taking suitable provisions to ensure a safe voting process for these COVID-19 vulnerable groups? (Question 1)

Other groups who are exposed to the risk of not exercising their right to vote are individuals who are infected with COVID-19 on Election Day (active cases), including those who are hospitalized or isolated, and individuals who are quarantined. These groups according to legislative measures are prohibited from leaving their homes or the environment where they are isolated or quarantined. If the first group of individuals who are mostly at risk for complications of been infected with COVID-19 choose not to go to the polls because of the potential of endangering their health, the individuals that are infected with COVID-19 or are quarantined do not have the right to choose due to administrative measure. Referring to the later they are prohibited from leaving the environment where they are being quarantined or treated.

But voters have the right to vote, regardless of whether they are sick or in quarantine (Salcedo, 2020). As established in the Constitution of Albania, Article 15, the bodies of public power in Albania, in fulfilling their duties, must respect fundamental human rights and freedoms, as well as contribute to their realization. Under this task, what is the contribution of the authorities in the realization of the right to vote for individuals infected with COVID-19 or quarantined? (Question 2)

Taking into consideration the typology of the disease, the citizens themselves play an important role in protecting their health. In states that have held elections in the context of COVID-19, health and electoral authorities undertake informative campaigns to sensitize citizens if they are infected with COVID-19, isolated, or quarantined to stay at home on the voting day to protect the lives of others. Voters need to adopt what ethicists call "the precautionary principle", whereby people take steps to avoid or reduce harms to others such as risking their life or health (Davidson, 2020). Nonetheless, it is quite important to note here that the responsible authorities had provided to these target groups the right to exercise their voting right through other alternative voting mechanisms.

Taking specific measures in the context of elections due to COVID-19 comes not only as a necessity and responsibility of states in organizing inclusive elections under the democratic principles that allow all citizens to exercise their fundamental rights but also as a condition to ensure high turnout in elections. Voter turnout is seen by many as a crucial factor underpinning the legitimacy of an election, providing electoral mandates to leaders, and as a barometer for the health of democracy in general (Lodman \& Splendore, 2020, pg.4). Of course, that voter turnout is assumed to be relative to several factors ranging from conviction and trust in institutions to socio-economic 
determinants, however, can be located in prevailing political behavior. (Salihu et.al 2021, pg.3).

As Baccini et al. mentioned in their research on the impact of COVID19 on the Presidential Election in America, many studies link shocks, such as natural disasters, to political behavior (Abney \& Hill, 1966; Chen, 2012; Malhotra \& Kuo, 2008; Bechtel \& Hainmueller, 2011). More specifically, Lodmand and Splendore argued that the COVID-19 pandemic poses significant risks to the ability of countries to guarantee genuine and transparent elections. Also, without well-considered and appropriate measures, the conduct of elections may have a significant impact on both public health protection and electoral integrity (Lodman \& Splendore, 2020, pg.1). According to Davidson's study regarding the ethics of not voting, he argued that the three most common reasons are: "I don't have enough information", "I don't like any of the candidates", and "I don't want to give this election legitimacy". More so, in the current context of the pandemic, another reason is the precautionary principle (Davidson, 2020).

Thus, this research paper is an attempt to answer the two questions raised above (Question $1 \& 2$ ). This research paper was based on the methodology of interpretation of norms of applicable law, instructions, and measures in Albania, and the comparative method was used as a supplementary method during the assessment of these measures. To realize the latter, the measures implemented by the countries that had held elections during COVID-19 Pandemic and the recommendations of various International Institutions, Organizations or Manuals regarding the Election and COVID-19 were compared. The novelty of this research paper adheres to the evaluation of the measures taken so far by responsible authorities to ensure without exception the fundamental right to vote to all voters in Albanian. In the following, the measures and tools implemented during the election are analyzed in two different sections. In the first section, the measures undertaken for vulnerable groups such as the elderly and people with certain medical conditions are evaluated. The precautions that Albanian authorities have envisaged to undertake to ensure the right to vote to voters that are in isolation or quarantined are treated in the second section.

\section{Cartain at-Risk group and the Right to Vote}

There are three different groups referred to as COVID-19 vulnerable groups. These group of people require extra precautions to protect themselves from getting COVID-19 such as the elderly because the risk or severe illness with COVID-19 increase with ages: people with certain medical conditions; people at increased risk, and those who visit or live with them (CDCP, 2021). It is well known that the first group includes people over 65 years. Therefore, to specify who belongs to the second group, it is important to undertake a 
theoretical framework regarding the diseases that the health authority include in certain medical conditions, severe illness, etc.

Individuals infected with SARS- CoV- 2 manifested different symptoms, and according to health institutions they can be categorized as follows: Asymptomatic or Presymptomatic, Mild Illness, Moderate Illness, and illness. The voters belonging to the last group are the subject of this research paper. Severe illness means that a person with COVID-19 may require hospitalization, intensive care, a ventilator to help them breathe, or they may even die (Center for Disease Control and Prevention, 2021). Chronic medical conditions - what many may call "underlying conditions" - include diabetes, heart disease, obesity, cancer, and kidney disease. Elderly patients are also at a higher risk of severe illness (Jones, 2020). Underlying health conditions are long-term illnesses that people already have, which affect their health adversely. Multiple studies have also shown that if they were to contract COVID-19, they would be seriously at risk because the majority of the illnesses already affect the body's ability to fight off infection (Hunt, 2021).

In the first phase of the COVID-19 pandemic, as a novel virus, the information gotten by health authorities and medical institutions was limited. They include underlying medical problems like cardiovascular, diabetes, chronic respiratory disease, and cancer that are more likely to develop serious illness (World Health Organization, 2020). Thus, it has been over a year that several attempts had been made by health researchers to create a more extensive list of comorbidities diseases that in case of infection with SARS$\mathrm{CoV}-2$, people are more likely to manifest health complications. More specifically, the NHS has separated the conditions into two categories: high risk (clinically extremely vulnerable people) and moderate risk (clinically vulnerable people) (Hunt, 2021).

On the other hand, Centre for Disease Control and Prevention (2021), through the categorization of the empirical data for a correlations between concomitant diseases and severe illness from COVID-19, grouped the diseases into three main groups: Limited Evidence, Mixed evidence, and Strongest and most consistent evidence. The two last are included in the successive disease: Cancer; Chronic kidney; Severe Obesity; Type 2 diabetes mellitus; Chronic obstructive pulmonary disease, Obesity, Heart conditions such as cardiomyopathies, heart failure, artery or coronary disease; Smoking; Pregnancy; Hypertension; Sickle cell disease; Smoking; Solid Organ Transplants; Cerebrovascular disease; use of corticosteroids, or the use of other immune weakening medicines (Centre for Disease Control and Prevention: People with Certain Medical Conditions, 2021). Despite the age, every individual that suffers from one of the above diseases are faced with severe illness if they are infected with COVID-19. 
While each country adopted its own approach to holding safe elections during COVID-19, typical measures included mask wearing, social distancing, temperature checks, sanitizing, and single use of voting pencils; some countries also increased the number of polling stations, extended voting hours, offered mobile polling stations, or made accommodations for advance voting or priority voting for certain at-risk groups (Calva, 2021).

In order to protect the health of vulnerable groups with the purpose of minimizing crowding of voters at the polling stations, one of the mechanisms implemented was the early voting and/ or multiple day voting. For example, in New Zealand the election started two days earlier; in Canada the advance polling was applied before the pandemic; but in the 2020 election the number of days increased from 4 to 10 . However, such arrangements have different negative aspect such as: extra staffing; the polling centres in many countries are school buildings and they have to be available for more days of voting procces; and last but not less important sensitive materials including the ballots and ballot box must be kept secure over the voting period (The Commonwealth, Managing Elections in the Context of COVID-19, 2020).

In these 30 years of post-communism in Albania, the contestation of elections by political parties due to allegations of manipulation of the voting process, manipulation of the ballot boxes has become, unfortunately, almost a tradition that occurs in every election. Also, in the Electoral Code of Albania, it is specified that the elections are to be conducted on one of the last two Sundays within the electoral period, which is set by a decree by the President of the Republic (Article 9). From the above, the implementation of multiple days voting is not suitable to be applied in Albania, at least in the April 25 parliamentary election.

Other states such as Singapore, Nigeria, Malaysia etc... applied morning or specific time- bands for elderly and COVID-19 vulnerable groups. This measure was also accompanied by recommendations to individuals, who do not belong to these groups, not to vote during these specific hours. The implementation of this mechanism during the election in the context of the pandemic in Albania is an appropriate measure to protect the health of voters. Election management institutions in cooperation with health authority, using statistical data or through self-request of voters belonging to these COVID-19 vulnerable groups, should carefully determine these time bands.

The reallocation of polling locations from nursing homes, long-term care facilities, and senior living residences to help protect older adults and those with underlying medical conditions from potential COVID-19 exposure (Centre for Disease Control and Prevention, 2021) was another in-person voting measure suggested by CDC. According to Electoral Code of Albania, Chapter IV, Article 62, Special Institutions constitute a special polling unit and A voting centre in such institutions is established when there are more 
than 15 voters. "Special institutions" are prisons, places of pre-trial detention, as well as hospitals or other healthcare institutions that accept patients for more than three days (Electoral Code of Albani, Chapter I/ Article 2). The mayor of the local government unit determines and publishes the location of the voting center, not less than 40 days prior to the election date (Electoral Code of Albani, Chapter IV, Article 62).

If so far has been assessed the possibility to implement in Albania the measures applied by other countries that have held elections in pandemic time, the following part of this section is focused on answering one of the questions raised above in this research paper. What are the specific actions and measures taken by the Albanian authorities to facilitate the voting process for these COVID-19 at-risk groups? Referring to the Constitution of Albania, the Central Election Commission (hereafter CEC) is a permanent organization that prepares, supervises, manages, and verifies all aspects of elections and referenda and announces their results (The Albanian Constitutions, Article 153).

Examining the decisions published by CEC, it can be concluded that there is still no specific instruction or measures to increase security during the voting process for this specific group. In addition, it is worth noting that while only two months separate us from the election, the measures that will be taken by the Albanian authorities to hold safe elections in the context of COVID-19 are neither predicted nor articulated. It is important to highlight that health and electoral management authorities have not yet promulgated manuals for a safe voting process for these vulnerable groups.

\section{Isolated/ Quarented/ Hospitalized Voters and the Right to Vote}

States that have held election/ referendums from 2020 have given special attention to ensure the right to vote by voters who were infected with COVID-19, hospitalized, or quarantined, including those who show symptoms of the virus on the voting day. Taking precautionary measures and forecasting different voting instruments for individuals who are in one of the above conditions is important considering the epidemiological data of the recent weeks in Albania (there is a growing curve of new cases and active cases infected with COVID-19 since the beginning of the pandemic). But even if the statistical data would not be high as mentioned before, the right to vote is an inalienable right and voters have the right to vote, regardless of whether they are sick or in quarantine (Salcedo, 2020). Due to the typology of the virus, it is very important that the measure to be taken should be flexible, in order to enable the participation of individuals who may show symptoms on the day of voting or receive the results of their medical analysis recently.

There is often confusion between the concept of quarantine and isolation because in both cases, individuals have to stay at home. Oftentimes, 
these words are used interchangeably. According to the Center for Disease Control and Prevention: a. Isolation is for people who have tested positive for COVID-19 and requires people to stay in their homes for at least 10 days while monitoring symptoms; b. Quarantine is for people who have been in contact with someone who has COVID-19 and requires staying at home for at least 14 days while monitoring symptoms (Pratt, 2020).

In Albania, there are specific procedures if an individual reports any contact with a suspected, potential, or confirmed case of 2019 n-CoV-2. They should report it to the relevant Local Health Care Unit immediately. Thereafter, he /she completes the investigation form, and this procedure should be performed within 24 hours (Ministry of Health in Albania, 2020). After taking the COVID-19 test, taking into consideration the unknowns of this disease, the individuals should stay in self-quarantine for 14 days despite the results of the test. If the case is confirmed positive, contacts should be selfquarantined or should stay in an environment adapted as quarantine to ensure social distancing by applying the rules of quarantine (Public Health Institution in Albania, 2020). From the above, it is very important that even for the close contact with suspected, potential, or confirmed cases of COVID-19, the responsible authority should take all necessary measures to enable the right to vote in the April 25 election.

The alternative voting methods undertaken by countries to ensure the rights to vote by these groups may be classified into two main categories: Inperson voting at polling stations and non-in-person voting at polling stations.

\section{- Voting Mechanisms in-Person at Polling Station}

Consulting the state's legal framework, the appropriate authority should consider implementing alternative voting options that minimizes the interaction between polling commissioners and voters, or voters with each other, such as Special voting sites that allow election officials to take additional, dedicated precautions for mitigating the risk of COVID-19 spread at those sites (this includes specialized training for poll workers and heightened requirements for the use of personal protective equipment), and curbside or drive-through voting (Election Assistance Center in US, 2020).

The success of the above measures also depends on individual responsibility, coordination between polling station staff and health authorities who maintain epidemiological data of individuals who are suspected, potential, or confirmed cases of COVID-19. Applying optional measures such as designing polling sites or curbside voting for sick voters in Albania is relatively difficult. This is because the principle of voting secrecy can be compromised due to the reduced number of voters. Referring to the Electoral Code of Albania, one polling station was composed of a minimum of 200 to a 
maximum of 1000 voters. Referring to the last parliamentary elections of 2017 , the participation of citizens nationwide was $46.77 \%$. Assuming that in a polling station with 1000 voters based on the percentage of previous elections, it can be predicted that about 470 individuals will vote. Despite the methodological problems that this assumption may have, it can be deduced that individuals who are diagnosed with COVID-19 or have been quarantined if they will vote in separate ballot boxes at polling stations they can be easily identifiable. This problem becomes even bigger if polling stations are in rural areas where not only the number of voters is smaller but also the number of infected individuals is even smaller.

As previously described, a dedicated polling center is another inperson voting mechanism. The creation of polling stations in Special Institution under the electoral code in Albania can be a useful tool. Therefore, it is important to emphasize that this mechanism provides the possibility to vote only by the hospitalized voters. Even though the election date is not very far away, it has not yet been publicly articulated whether special polling stations will be set up specifically for these vulnerable groups.

Although it is not a direct instrument, under the "principle of precaution", a series of states through intense informative campaigns discourage anyone with symptoms from entering the polling location building (Centre for Disease Control and Prevention, 2021). It is important to note that these states have provided citizens with alternative non-person voting methods that will be analyzed in detail below.

- Non in-Person Voting Mechanisms

Special Voting Arrangements (hereafter SVA) can be defined as arrangements that allow voters to exercise their right to vote by alternative means other than casting a ballot in person at their respective polling station on election day. In total, 32 out of 51 countries (63 percent) that have held national elections or referendums in 2020 made use of at least one SVA (Asplund et al., 2021).

One of the non in-person voting mechanisms is Proxy voting, which is the criteria for the implementation of these SVA depending on the county. For example in same cases, one voter can authorise up to one proxy vote to prevent the last moments emergency. Also, different countries establish facilities for voters because due to COVID-19, they could not go to the office or establish a proxy vote could request that an agent (police officer or person duly authorized) come to their place of confinement (International Foundation for Electoral Systems, October 21, 2020. Pg. 8.) Other measures implemented for these groups were traditional SVA such as voting by email, mail, via posta, etc. 
As assessed in the case of the mechanism to ensure safe voting for individuals COVID-19 at-risk groups, we will first analyze the measures and the legal possibility of the implementation of SVA in Albania. Second, we will describe the steps undertaken by Albanian responsible authority to provide alternative voting. The realization of this analysis enables us to answer the second scientific question of this paper. In Albania "voting for third parties" is illegal and punishable under the Criminal Code of the Republic except in cases when assisted voting takes place according to this law (Electoral Code of the Republic of Albania, Article 2, and point 29). The process of assisted voting is well regulated on the Article 108 of Electoral Code which states that: Assisted voting is provided only for those voters who, for physical reasons, are unable to perform the voting procedures him/her self. Within the period of the revision of voter's lists, they have the right to request the mayor of the local government unit that prepares the voter list for the respective voting centre to register them as voters who cannot vote themselves (the request for registration is accompanied by the official documentation that proves the type and category of disability). The deadline for submitting such a request is within the voter list review period which is 60 days before the voter date, which is until February 25, 2021. In order to apply the assisted voting, three essential conditions must be met: a. Before marking the ballot paper, a person who assists another voter makes a statement in the VCC Meeting Record Book that he/she will vote as instructed, will not influence the voter's decision, will not make the vote public and has not voted on behalf of any other voter (point 3 ); b. The voters should be at the same voter list of the polling unit; c. Both voters must be present in the voting center when this procedure is used ( point 1, Article 108).

From the above, it can be easily deduced that the voting of individuals who are diagnosed with COVID-19 or who are self-isolated so far has not been provided in any legal act or sub-legal act. Even if Albania decides to apply one of the Special Voting Arrangements, it should not ignore one of the essential recommendations of International IDEA regarding the Special Voting Arrangements $(\mathrm{SVA}=$ such as mobile voting, postal voting, email voting, proxy voting etc..). The state has to be very careful if they decide to implement these methods during the election for the first time and to take into consideration four important success factors: Broad support, reasonable timelines, ideally already existing legal frameworks, and prior experience with SVA. Introducing them too fast and without broad stakeholder buy-in is problematic (International Institute for Democracy and Electoral Assistance, 2020). 


\section{Conclusion}

On April 25, Albania will hold an election during the ongoing COVID19 Pandemic, and like many other states that conducted elections in the same circumstances, the authority will deal with the responsibility of providing safe elections and guarantee the right to vote to all voters. The evaluation of the documents approved until now by the responsible authority in Albania for the management of election (such as decisions, guidelines, orders, etc.) lead to the conclusion that there is a pressing need. In addition to standard measures to increase security at polling stations, e.g., physical distancing, the establishment of disinfection centers, use of masks, gloves and special protection for polling station staff, the Albanian authorities should take several specific measures addressed to the most vulnerable groups such as people infected with COVID-19, elders, active cases with COVID-19, and quarantined voters or those who may get infected on the voting day.

The responsible authorities are now at the limits of time to decide what measures should be taken because after approval of the strategy for safe election, they must proceed with an essential process: the education of citizens. They had to undertake informative campaigns, where it is worth noting that these vulnerable groups are even difficult to reach. Of course, this is a complex process and requires cooperation between stakeholders, health institutions, etc.

The Albanian authorities should take into account that the lack of the appropriate measures will make citizens, especially vulnerable groups mentioned above, to choose between their health or exercising their right to vote, and turning COVID-19 into a potentially influential factor in the reduction of citizen participation in the parliamentary election of April 25, 2021.

\section{References:}

1. Asplund, E et al. (2021). Elections and Covid-19: How special voting arrangements were expanded in 2020. IDEA. Retrieved from: https://www.idea.int/news-media/news/elections-and-covid-19-howspecial-voting-arrangements-were-expanded-2020

2. Baccini, L., Brodeur, A. \& Weymouth, S. (2021). "The COVID-19 pandemic and the 2020 US presidential election". J Popul Econ 34, 739-767. https://doi.org/10.1007/s00148-020-00820-3

3. Brennan Center for Justice \& Infection Diseases Society of America (2020). "Guidelines for Healthy in-Person Voting." Retrieved from: https://www.brennancenter.org/sites/default/files/202008/2020_08_Guide\%20for\%20Healthy\%20In\%20Person\%20Voting _Finalv2.pdf 
4. Calva, L. (2021). "The virus and the Votes: How is COVID-19 changing voter tournout in LAC?. UNDP". Reitrived form : https://www.latinamerica.undp.org/content/rblac/en/home/presscenter /director-s-graph-for-thought/the-virus-and-the-votes--how-is-covid19-changing-voter-turnout-.html

5. Centre for Disease Control and Prevention (2021). "People with Certain Medical Conditions". Retrived from:

https://www.cdc.gov/coronavirus/2019-ncov/need-extra-

precautions/people-with-medical-conditions.html\#chronic-kidneydisease

6. Centre for Disease Control and Prevention (2021). "Elections \& Voting-Interim guidance to prevent spread of coronavirus disease 2019 (COVID-19)'. Retrieved from:

https://www.cdc.gov/coronavirus/2019-ncov/community/electionpolling-locations.html

7. Constitution of the Republic of Albania (1998). Approved by referendum on 22 November 1998, promulgated on 28 November 1998, amended in January 2007.

8. Davidson, S. (2020). "Why there is no ethical reason not to vote (unless you come down with COVID-19 on Election Day)". The Conversation. Retrieved from: https://theconversation.com/uk/whowe-are

9. Election Assistance Commission in US. "Assisting Sick, Exposed, Symptomatic, and Quarantined Voters." Retrieved from: https://www.eac.gov/sites/default/files/electionofficials/gcc/Assisting _Sick_Exposed_Sympomatic_and_Quarantined_Voters_092920.pdf

10. European Centre for Disease Prevention and Control (2020). "Questions and answers on COVID-19: Medical information". Retrived from:

https://www.ecdc.europa.eu/en/covid-19/facts/questions-answersmedical-info

11. Ferguson, S., Young, L. et al. (2003). "Study Guide: The Right to Vote." University of Minnesota Human Rights Center. Reitrived from: http://hrlibrary.umn.edu/edumat/studyguides/votingrights.html

12. Hunt, A. (2021). What are the underlying health conditions that put you at greater risk of severe illness with coronavirus? Retrieved from: https://www.goodto.com/wellbeing/health/underlying-healthconditions-coronavirus-533291

13. International Foundation for Electoral Systems (2020). "Featured Elections Held and Mitigating Measures Taken During COVID-19."

14. International Institute for Democracy and Electoral Assistance (2020). Issues, Challenges and Protocols for Conducting Elections during 
COVID-19: Sharing Country Experience. Retrieved from: https://www.idea.int/news-media/media/issues-challenges-andprotocols-conducting-elections-during-covid-19-sharing

15. Jones, J. (2020). "What's an Underlying Condition?". Baton Rouge General. Retrieved from: https://www.brgeneral.org/newsblog/2020/march/whats-an-underlying-condition-/

16. Landman, T. \& Splendor, G.L. (2020). "Pandemic democracy: elections and COVID-19". Journal of Risk Research, 23:7-8, 10601066, DOI: 10.1080/13669877.2020.1765003

17. Noury, A., François, A., Gergaud, O., \& Garel, A. (2021). "How does COVID-19 affect electoral participation? Evidence from the French municipal elections.". PLOS ONE 16(2): e0247026.

https://doi.org/10.1371/journal.pone.0247026

18. Pratt, E. (2020). "There's a difference Between Quarantine and Isolation: What You Should Know". Retrieved from: https://www.healthline.com/health-news/covid19-quarantineisolation-differences-guidelines

19. Public Health Institution (2020). Frequently Asked Questions: The virus and the disease from COVID-19. Retrieved from: https://www.ishp.gov.al/pyetje-dhe-pergjigje-te-shpeshta-virusi-dhesemundja-nga-covid-19/

20. Salcedo, A (2020). "Isolating after a positive coronavirus test? The CDC says you can still vote in person'. Washington Post. Retrieved from:

https://www.washingtonpost.com/nation/2020/11/03/cdc-covid-19vote-election/

21. Salihu, M. \& Yakubu, Y. (2021). "Election Violence and Voter Turnout in 2019 General Elections: What Role for Political Parties?". European Scientific Journal, ESJ, 17(2), 137. https://doi.org/10.19044/esj.2021.v17n2p137

22. The Commonwealth (2020). Managing Elections in the Context of COVID-19: Perspectives from the Commonwealth. Commonwealth Elections and COVID-19 Briefing Paper, Issues 1. Retrieved from:https://hecommonwealth.org/sites/default/files/inline/Elections $\% 20$ and \%20C19\%20Perspectives\%20from\%20CW\%20FN.pdf

23. The Electoral Code Of The Republic Of Albania (Approved by Law no. 10 019, dated 29 December 2008, amended by Law no. 74/2012, dated 19 July 2012 and Law no. 31/2015, dated 2 April 2015, Low. 101/2020 dated 23.07.2020 and Low. 118/2020 dated 5 October 2020).

24. United National News (2020). "Human rights must be 'front and center' of COVID-19 response: Secretary-General." Retrieved from: https://news.un.org/en/story/2020/12/1079632 
25. World Health Organization (2020). "Coronavirus: an Overview." Retrieved from https://www.who.int/health-topics/coronavirus\#tab=tab_1 